\title{
MARKOWITZ MODEL DALAM PEMBENTUKAN PORTOFOLIO OPTIMAL (STUDI KASUS PADA JAKARTA ISLAMIC INDEX)
}

\section{MARKOWITZ MODEL IN OPTIMAL PORTFOLIO FORMATION (CASE STUDY IN JAKARTA ISLAMIC INDEX)}

Irni Yunita

Telkom University, Padjadjaran University

Faculty of Economy and Business, Bandung, Indonesia

Irniyunita81@yahoo.com, Irniyunita@telkomuniversity.ac.id

JURNAL

MANAJEMEN

INDONESIA

Vol.18 No.1

April 2018

\begin{abstract}
Abstrak
Tujuan dari penelitian ini adalah untuk menentukan pemilihan portofolio optimal menggunakan model Markowitz. Penelitian ini menggunakan data time series dari tahun 2013 - 2018. Sampel penelitian terdiri dari 29 saham yang terdapat dalam Jakarta Islamic Index tahun 2018. Hasil penelitian menunjukkan bahwa terdapat 10 saham yang termasuk ke dalam portofolio optimal yaitu antara lain AKRA (3.4\%), ADRO (3.3\%), ICBP (4.7\%), INCO (2.6\%), MYRX (13.6\%), PTPP (4.9\%), PWON (11.3\%), TPIA (1\%), UNTR $(15.7 \%)$ dan UNVR $(39.5 \%)$. Rata rata tingkat pengembalian portofolio adalah sebesar $1.22 \%$ dan resiko portofolio adalah sebesar 0.0312 , resiko tersebut di bawah resiko dari masing-masing saham individual pembentuk portofolio optimal.
\end{abstract}

Kata kunci : Jakarta Islamic Index, Model Markowitz, Pemilihan Portofolio Optimal

\section{Abstract}

The purpose of this study is to determine the optimal portfolio selection using the Markowitz model. This study uses time series data from 2013 to 2018. The study sample consisted of 29 stocks contained in the Jakarta Islamic Index in 2018. The results showed that there are 10 stocks included in the optimal portfolio: AKRA (3.4\%), ADRO (3.3\%), ICBP (4.7\%), INCO (2.6\%), MYRX (13.6\%), PTPP (4.9\%), PWON (11.3\%), TPIA (1\%), UNTR (15.7\%) and UNVR (39.5\%). The average portfolio return rate is $1.22 \%$ and the portfolio risk is 0.0312 , the risk is below the risk of each individual stock of the optimal portfolio.

Keywords : Jakarta Islamic Index, Markowitz Model, Optimal Portfolio Selection

\section{Pendahuluan}

Investasi merupakan komitmen terhadap sejumlah dana dengan harapan menghasilkan tambahan dana dan tingkat pengembalian yang positif (Fischer and Jordan, Francis dalam Ahmad, 2004). Hampir semua investasi mengandung unsur ketidakpastian atau resiko. Setiap investor harus dapat memperkirakan resiko investasi yaitu sejauh mana kemungkinan hasil yang sebenarnya nanti akan menyimpang dari hasil yang diharapkan dan memperkirakan berapa keuntungan yang akan didapatkan. Ketika investor menghadapi kesempatan investasi yang beresiko, pilihan investasi tidak hanya dapat mengandalkan pada tingkat keuntungan yang diharapkan, namun juga harus bersedia untuk menanggung resiko yang tinggi pula (Husnan, 2005). Investor melakukan investasi untuk mendapatkan hasil yang maksimal dengan resiko yang minimal. Untuk meminimalkan tingkat kerugian atau resiko yang tinggi, sebaiknya investor menempatkan modal pada berbagai jenis instrumen investasi seperti saham, obligasi atau deposito. Gabungan dari berbagai jenis instrumen investasi tersebut disebut dengan portofolio (Zubir, 2011).

Hubungan antara resiko dan return dikembangkan oleh Harry Markowitz pada tahun 1952 dengan memperkenalkan proses pemilihan portfolio. Markowitz menekankan bahwa investor menganalisis dan memilih suatu sekuritas berdasarkan pada expected return dan varians return sekuritas tersebut. Teori portfolio mengimplikasikan bahwa untuk dapat 
menerima resiko yang lebih besar, investor harus dikompensasi dengan kesempatan untuk mendapatkan return yang besar pula (Fabozzi, 1995 dalam Zubir, 2011).

Dalam melakukan investasi di pasar modal, investor dapat membentuk portofolio saham dengan diversifikasi saham yaitu memilih saham-saham yang didasarkan pada return dan resiko dan selanjutnya membentuk portofolio yang optimal dari saham-saham tersebut. Pembentukan portfolio diantaranya menentukan aset yang akan dipilih untuk dijadikan investasi dan menentukan besarnya proporsi jumlah dana yang akan ditempatkan ke dalam investasi. Menurut Sharpe et al. (2005), selektivitas, penentuan waktu dan diversifikasi merupakan hal yang penting dalam pembentukan portofolio.

Dalam menentukan pemilihan portofolio saham, permasalahan terbesar adalah pada saat memilih saham-saham yang akan dijadikan kandidat portofolio. Untuk mempermudah proses pemilihan portofolio, dapat melakukan pemilihan saham dalam indeks tertentu di pasar modal. Di pasar modal Indonesia, terdapat kelompok saham yang termasuk ke dalam saham syariah. Saham syariah merupakan saham-saham yang memenuhi kriteria syariah dimana perusahaannya merupakan perusahaan yang tidak melakukan usaha judi, ribawi, tidak menjual makanan dan minuman yang haram, tidak memproduksi, mendistribusikan barang barang yang merusak moral dan bersifat mudharat dan sumber hutang perusahaan yang tidak lebih dari 30\% rasio modalnya (Umam, 2013). Di pasar modal Indonesia, saham-saham syariah tergabung dalam indeks syariah, salah satunya Jakarta Islamic Index (JII). Perkembangan Indeks JII dari tahun 2003 sampai 2018 mengalam peningkatan setiap tahunnya, dapat dilihat pada gambar 1 .

Gambar 1. Perkembangan Jakarta Islamic Index, 2013-2018

Sumber : data diolah dari www.yahoofinance.com (2018)

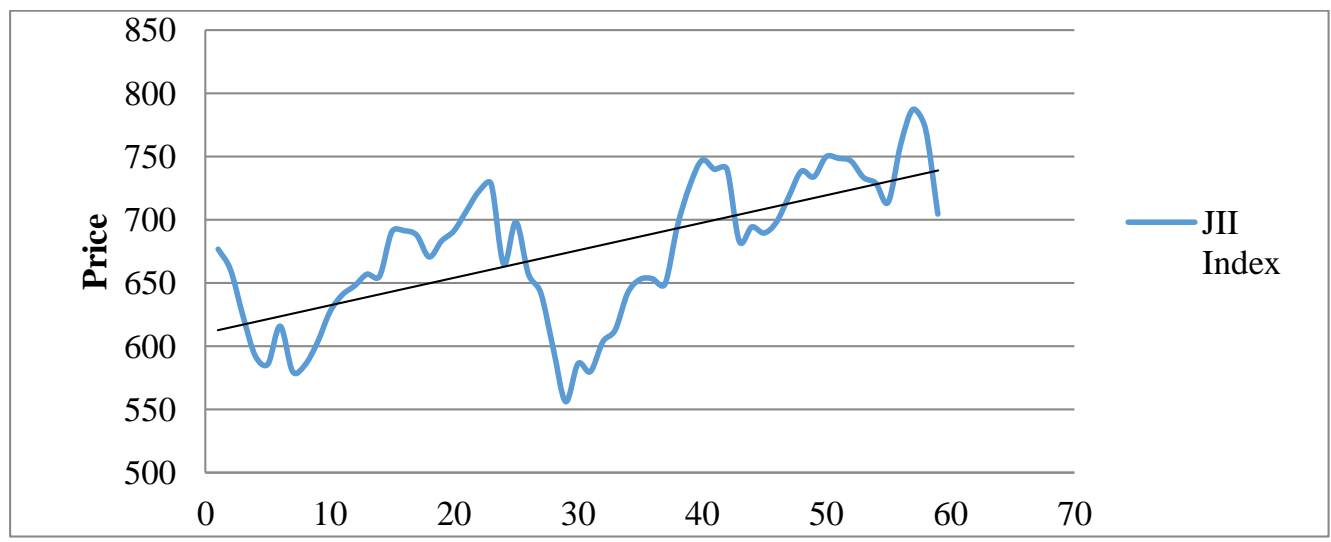

Dari Gambar 1. menunjukkan terjadinya trend peningkatan Jakarta Islamic Index dari tahun 2013 - 2018. Kondisi tersebut membuat saham-saham yang terdapat di dalam indeks JII layak untuk dipilih menjadi kandidat dalam pembentukan portofolio optimal. Pemilihan saham-saham pada indeks JII didasarkan pada model pemilihan portofolio dengan menggunakan model Markowitz yang meyakini bahwa penambahan saham secara terus menerus pada satu portofolio, pada satu titik tertentu akan semakin mengurangi manfaat diversifikasi dan justru akan memperbesar tingkat resiko (Septyanto dan Keropati, 2013) sehingga sampel pada penelitian ini dipilih hanya pada saham-saham yang terdapat dalam indeks JII.

\section{Tinjauan Pustaka}

\subsection{Investasi}

Investasi adalah menempatkan uang atau dana dengan harapan memperoleh tambahan atau keuntungan tertentu atas uang atau dana tersebut (Ahmad, 2004). Terdapat dua jenis investasi yaitu investasi nyata dan investasi keuangan. Investasi nyata termasuk investasi ke dalam asset-aset yang berwujud seperti tanah dan pabrik. Investasi keuangan melibatkan kontrak tertulis seperti saham (Sharpe et al., 2005).

Jurnal Manajemen Indonesia 
Proses investasi berkenaan dengan keputusan mengenai pemilihan sekuritas, seberapa banyak investasi dilakukan dan waktu pelaksanaan investasi (Sharpe et al., 2005). Terdapat 5 tahap dalam keputusan investasi (Tandelilin, 2017) : (1) Menentukan Tujuan Investasi, (2) Menentukan kebijakan investasi, (3) Pemilihan strategi portofolio, (5) Pemilihan aset, dan (5) Pengukuran dan Evaluasi kinerja Portofolio.

Pada tahap pertama, pemodal perlu menentukan tujuan investasinya dan berapa banyak investasi tersebut akan dilakukan. Tahap kedua, investor melakukan analisis terhadap individual sekuritas. Ketiga, pembentukan portofolio. Portofolio berarti sekumpulan investasi. Tahap ini menyangkut identifikasi sekuritas mana yang akan dipilih, dan berapa proporsi dana yang akan ditanamkan pada masing-masing sekuritas tersebut. Tahap keempat melakukan perubahan terhadap protofolio yang dimiliki. Tahap kelima, pemodal melakukan penilaian terhadap kinerja portofolio, baik dalam aspek tingkat keuntungan maupun resiko yang ditanggung (Husnan, 2005).

\subsection{Saham}

Saham merupakan salah satu bentuk investasi langsung (Jogiyanto, 2016). Saham biasa adalah sertifikat yang menunjukkan bukti kepemilikan terhadap suatu perusahaan (Tandelilin, 2017). Pemegang saham memiliki hak suara dalam Rapat Umum Pemegang Saham (RUPS) dan disamping memperoleh deviden dari perusahaan, juga kemungkinan mendapatkan keuntungan atas kenaikan harga saham (capital gain) (Ahmad, 2005).

\subsection{Saham Syariah}

Dalam Islam, saham pada hakikatnya merupakan modifikasi sistem patungan (persekutuan) modal dan kekayaan, yang dalam istilah fiqih dikenal dengan nama syirkah (Susanto, 2008). Efek Syariah adalah Efek yang akad, cara, dan kegiatan usaha yang menjadi landasan penerbitannya tidak bertentangan dengan prinsip-prinsip syariah di Pasar Modal (www.idx.co.id). Jakarta Islamic Index (JII) merupakan indeks yang terdapat di Bursa Efek Indonesia (BEI) yang berisi 30 saham perusahaan yang memenuhi kriteria investasi berdasarkan syariah Islam, diantaranya (Jogiyanto, 2016): (1) saham terpilih harus sudah tercatat paling tidak 3 bulan terakhir, kecuali saham yang termasuk ke dalam 10 kapitalisasi besar, (2) mempunyai rasio hutang terhadap aktiva tidak lebih dari 90\% di laporan keuangan tahunan atau tengah tahun, (3) dari yang masuk kriteria no 1 dan 2, dipilih 60 saham dengan urutan rata-rata kapitalisasi pasar terbesar selama satu tahun terakhir, (4) Kemudian dipilih 30 saham dengan urutan tingkat likuiditas rata-rata nilai perdagangan regular selama satu tahun terakhir.

\subsection{Teori Portofolio}

Hampir semua sekuritas yang tersedia mengandung ketidakpastian atau resiko. Investor dihadapkan pada masalah pemilihan sekuritas beresiko yang harus dipilih.Investor harus dapat memilih portofolio optimal dari kumpulan portofolio yang tersedia (Sharpe et al., 2005). Portofolio optimal ditentukan dari portofolio efisien yang merupakan portofolio yang memberikan return ekspektasi terbesar dengan resiko yang sudah tertentu atau memberikan resiko yang terkecil dengan return ekspektasi yang sudah tertentu (Jogiyanto, 2016). Portofolio optimal dapat ditentukan dengan menggunakan model Markowitz. Langkahlangkah dalam menentukan portofolio optimal dengan menggunakan model Markowitz adalah sebagai berikut (Jogiyanto, 2016):

a. Menghitung Return tiap saham

$$
\begin{aligned}
& \mathrm{R}_{\mathrm{it}}=\frac{P_{t}-P_{t-1}}{P_{t-1}}+\frac{D_{t}}{P_{t-1}} \\
& \mathrm{R}_{\mathrm{it}}=\text { Return pada waktu yang diharapkan } \\
& \mathrm{P}_{\mathrm{t}-1}=\text { Harga Investasi periode lalu } \\
& \mathrm{P}_{\mathrm{t}}=\text { Harga Investasi sekarang }
\end{aligned}
$$


b. Menghitung Expected Return saham

$$
\mathrm{E}(\mathrm{Ri})=\frac{\sum_{i=1}^{n} \text { Rit }}{n}
$$

JURNAL

MANAJEMEN

INDONESIA

Vol.18 No.1

April 2018 c. Menghitung Varians saham

$$
\sigma \mathrm{i}^{2}=1 / \mathrm{n} \sum\left(\mathrm{R}_{\mathrm{it}}-\mathrm{E}(\mathrm{Ri})\right)^{2}
$$

d. Menghitung Standar Deviasi Saham

$\sigma \mathrm{i}=\sqrt{\sigma_{\mathrm{i}}^{2}}$

e. Menghitung Kovarian antara dua saham dalam portofolio

$\sigma_{12}=\sum_{i=1}^{n} \frac{\left[\left(R_{1 i}-E\left(R_{1}\right)\right) \cdot\left(R_{2 i}-E\left(R_{2}\right)\right]\right.}{n}$

$\mathrm{R}_{1 \mathrm{i}}=$ return masa depan saham 1 kondisi ke- $\mathrm{i}$

$\mathrm{R}_{2 \mathrm{i}}=$ return masa depan saham 2 kondisi ke- $\mathrm{i}$

$\mathrm{E}(\mathrm{R} 1)=$ return expektasian saham 1

$\mathrm{E}(\mathrm{R} 2)=$ return expektasian saham 2

$\mathrm{N}$ = jumlah dari observasi data historis.

f. Menghitung Koefisien Korelasi antara dua saham

$\rho_{12}=\frac{\sigma_{12}}{\sigma_{1} \cdot \sigma_{2}}$

$\sigma_{12}=$ Kovarians saham 1 dan 2

$\sigma_{1}=$ Standar Deviasi Saham 1

$\sigma_{2}=$ Standar Deviasi Saham 2

g. Menentukan proporsi dana dari saham-saham kandidat portofolio. Dalam menentukan proporsi masing masing saham dalam portofolio optimal, dapat ditentukan dengan menggunakan metode penyelesaian optimasi. Metode penyelesaian optimasi dalam dilakukan dengan menggunakan paket pemrograman komputer untuk pemrograman kuadratik dengan program aplikasi Solver yang ada didalam Microsoft Excel. Aplikasi ini akan memberikan proporsi dana yang terbaik supaya menghasilkan return yang paling maksimal.

Fungsi objektif yang digunakan adalah fungsi resiko portofolio berdasarkan model Markowitz. Model penyelesaian optimasi ditulis sebagai berikut:

Fungsi Obyektif :

Minimumkan : $\sum_{i=1}^{n} w i . \sigma i .^{2}+\sum_{i=1}^{n} \sum_{j=1}^{n} w i . w j . \sigma i j$

Subyek terhadap kendala-kendala:

(1) $\sum_{i=1}^{n} w i=1$

(2) $w i \geq 0$ untuk $\mathrm{i}=1$ sampai dengan $\mathrm{n}$

(3) $\sum_{i=1}^{n}$ wi.Ri $=R p$

Dari aplikasi solver akan didapatkan nilai Expected Return dan Resiko portofolio optimal. Expected Return Portofolio : $E(R p)=\sum_{i=1}^{n}(w i . E(R i)$

Resiko Portofolio : $\alpha_{p}^{2}=\sum_{i=1}^{n} \sum_{j=1}^{n} w i . w j . \sigma i j$

\section{Metoda Riset}

Penelitian ini menggunakan data sekunder dengan jenis data time series periode Mei 2013 - Maret 2018. Data yang digunakan berupa data harga saham penutupan perusahaan yang terdaftar di Jakarta Islamic Index periode tahun 2018 dan Indeks penutupan IHSG sebagai indeks pasar. Data didapatkan dari www.idx.co.id dan www.yahoofinance.com. Populasi penelitian yaitu seluruh saham yang terdapat dalam Jakarta Islamic Index (JII) periode 2018. Penelitian ini menggunakan metode non purposive sampling dengan kriteria saham yang memiliki data harga saham penutupan yang lengkap dari Mei 2013 - Maret 2018.

\section{Jurnal Manajemen Indonesia}




\begin{tabular}{|c|c|c|c|c|c|c|c|c|}
\hline No & Kode & Perusahaan & No & Kode & Perusahaan & No & Kode & Perusahaan \\
\hline 1 & $\mathrm{ADRO}$ & Adaro Energy Tbk & 11 & INDF & $\begin{array}{l}\text { Indofood } \\
\text { Sukses } \\
\text { Makmur Tbk }\end{array}$ & 21 & SCMA & $\begin{array}{l}\text { Surya Citra } \\
\text { Media Tbk }\end{array}$ \\
\hline 2 & AKRA & AKR Corporindo Tbk & 12 & KLBF & $\begin{array}{l}\text { Kalbe Farma } \\
\text { Tbk }\end{array}$ & 22 & SMGR & $\begin{array}{l}\text { Semen Indonesia } \\
\text { (Persero) Tbk }\end{array}$ \\
\hline 3 & ANTM & $\begin{array}{l}\text { Aneka Tambang } \\
\text { (Persero) Tbk }\end{array}$ & 13 & LPKR & $\begin{array}{l}\text { Lippo } \\
\text { Karawaci Tbk }\end{array}$ & 23 & SMRA & $\begin{array}{l}\text { Summarecon } \\
\text { Agung Tbk }\end{array}$ \\
\hline 4 & ASII & $\begin{array}{l}\text { Astra International } \\
\text { Tbk }\end{array}$ & 14 & LPPF & $\begin{array}{l}\text { Matahari } \\
\text { Department } \\
\text { Store Tbk }\end{array}$ & 24 & TLKM & $\begin{array}{l}\text { Telekomunikasi } \\
\text { Indonesia } \\
\text { (Persero) Tbk }\end{array}$ \\
\hline 5 & BRPT & Barito Pacific Tbk & 15 & LSIP & $\begin{array}{l}\text { PP London } \\
\text { Sumatra } \\
\text { Indonesia Tbk }\end{array}$ & 25 & TPIA & $\begin{array}{l}\text { Chandra Asri } \\
\text { Petrochemical } \\
\text { Tbk }\end{array}$ \\
\hline 6 & BSDE & $\begin{array}{l}\text { Bumi Serpong Damai } \\
\text { Tbk }\end{array}$ & 16 & MYRX & $\begin{array}{l}\text { Hanson } \\
\text { International } \\
\text { Tbk }\end{array}$ & 26 & UNTR & $\begin{array}{l}\text { United Tractors } \\
\text { Tbk }\end{array}$ \\
\hline 7 & CTRA & $\begin{array}{l}\text { Ciputra Development } \\
\text { Tbk }\end{array}$ & 17 & PGAS & $\begin{array}{l}\text { Perusahaan } \\
\text { Gas Negara } \\
\text { (Persero) Tbk }\end{array}$ & 27 & UNVR & $\begin{array}{l}\text { Unilever } \\
\text { Indonesia Tbk }\end{array}$ \\
\hline 8 & EXCL & XL Axiata Tbk & 18 & PTBA & $\begin{array}{l}\text { Tambang } \\
\text { Batubara Bukit } \\
\text { Asam } \\
\text { (Persero) Tbk }\end{array}$ & 28 & WIKA & $\begin{array}{l}\text { Wijaya Karya } \\
\text { (Persero) Tbk }\end{array}$ \\
\hline 9 & ICBP & $\begin{array}{l}\text { Indofood CBP Sukses } \\
\text { Makmur Tbk }\end{array}$ & 19 & PTPP & $\begin{array}{l}\text { PP (Persero) } \\
\text { Tbk }\end{array}$ & 29 & WSKT & $\begin{array}{l}\text { Waskita Karya } \\
\text { (Persero) Tbk }\end{array}$ \\
\hline 10 & INCO & Vale Indonesia Tbk & 20 & PWON & $\begin{array}{l}\text { Pakuwon Jati } \\
\text { Tbk }\end{array}$ & & & \\
\hline
\end{tabular}

JURNAL

MANAJEMEN

INDONESIA

Vol.18 No.1

April 2018

Tabel 1.

Sampel Penelitian

Sumber : www.idx.co.id

(2018)

\section{Hasil dan Pembahasan}

\begin{tabular}{|c|c|c|c|c|}
\hline No. & Kode & $\mathbf{E}(\mathbf{R i})$ & Varians, $\boldsymbol{\sigma i} 2$ & Std Dev, $\boldsymbol{\sigma i}$ \\
\hline 1 & AKRA & 0.02060 & 0.01292 & 0.11367 \\
\hline 2 & ADRO & 0.02071 & 0.01345 & 0.11598 \\
\hline 3 & ASII & 0.00280 & 0.00429 & 0.06552 \\
\hline 4 & BPRT & 0.06042 & 0.04193 & 0.20477 \\
\hline 5 & BSDE & -0.00012 & 0.00681 & 0.08250 \\
\hline 6 & CTRA & 0.00382 & 0.01624 & 0.12745 \\
\hline 7 & EXCL & -0.00674 & 0.00983 & 0.09912 \\
\hline 8 & ICBP & 0.01532 & 0.02761 & 0.16618 \\
\hline 9 & INCO & 0.01365 & 0.02537 & 0.15929 \\
\hline 10 & INDF & 0.00189 & 0.00453 & 0.06729 \\
\hline 11 & KLBF & 0.00134 & 0.00351 & 0.05921 \\
\hline 12 & LPKR & -0.01505 & 0.00913 & 0.09555 \\
\hline 13 & LPPF & 0.00152 & 0.00906 & 0.09517 \\
\hline 14 & LSIP & 0.00184 & 0.01730 & 0.13153 \\
\hline 15 & MYRX & 0.00689 & 0.00911 & 0.09546 \\
\hline
\end{tabular}

Tabel 2.

Data Expected Return,

Varians dan Standar

Deviasi Saham

Sumber : Data diolah

(2018)

MARKOWITZ MODEL DALAM .. 


\section{JURNAL}

\section{MANAJEMEN}

\section{INDONESIA}

\section{Vol.18 No.1}

April 2018

\begin{tabular}{|c|c|c|c|c|}
\hline No. & Kode & $\mathbf{E}(\mathbf{R i})$ & Varians, $\boldsymbol{\sigma i 2}$ & Std Dev, $\boldsymbol{\sigma i}$ \\
\hline 16 & PGAS & -0.00810 & 0.01461 & 0.12088 \\
\hline 17 & PTBA & 0.01224 & 0.01843 & 0.13577 \\
\hline 18 & PTPP & 0.01411 & 0.01276 & 0.11295 \\
\hline 19 & PWON & 0.01546 & 0.00996 & 0.09982 \\
\hline 20 & SMRA & -0.00004 & 0.01442 & 0.12009 \\
\hline 21 & SCMA & 0.00188 & 0.00728 & 0.08534 \\
\hline 22 & SMGR & -0.00688 & 0.00510 & 0.07139 \\
\hline 23 & TPIA & 0.05366 & 0.02357 & 0.15352 \\
\hline 24 & UNTR & 0.01320 & 0.00489 & 0.06992 \\
\hline 25 & UNVR & 0.00944 & 0.00277 & 0.05265 \\
\hline 26 & WIKA & -0.00131 & 0.01286 & 0.11341 \\
\hline 27 & WSBP & -0.00689 & 0.00921 & 0.09595 \\
\hline 28 & WSKT & 0.02364 & 0.01701 & 0.13042 \\
\hline 29 & TLKM & -0.00131 & 0.00354 & 0.05947 \\
\hline
\end{tabular}

Dari Tabel 4.1 menunjukkan bahwa terdapat 20 saham yang memiliki expected return yang positif yaitu antara lain : AKRA, ADRO, ASII, BRPT, CTRA, ICBP, INCO, INDF, KLBF, LPPF, LSIP, MYRX, PTBA, PTPP, PWON, SCMA, TPIA, UNTR, UNVR dan WSKT sedangkan terdapat 9 saham yang memiliki expected return bulanan yang negatif selama periode pengamatan antara lain : BSDE, EXCL, LPKR, PGAS, SMRA, SMGR, WIKA, WSBP dan TLKM. Expected return saham bulan tertinggi yaitu saham BRPT (0.06) dan terendah yaitu LPKR (-0.015). Resiko saham tertinggi yaitu BPRT (0.04193) dan resiko saham terendah yaitu UNVR (0.0027).

\section{Tabel 3.}

Return Pasar (IHSG)

Sumber : Data diolah (2018)

\begin{tabular}{|c|c|c|c|c|c|c|c|c|}
\hline Tanggal & Close* & Return & Tanggal & Close* & Return & Tanggal & Close* & Return \\
\hline May 01, 2013 & $5,068.63$ & & Jan 01, 2015 & $5,289.40$ & 0.01 & Sep 01, 2016 & $5,364.80$ & 0.00 \\
\hline Jun 01,2013 & $4,818.90$ & -0.05 & Feb 01, 2015 & $5,450.29$ & 0.03 & Oct 01,2016 & $5,422.54$ & 0.01 \\
\hline Jul 01, 2013 & $4,610.38$ & -0.04 & Mar 01, 2015 & $5,518.68$ & 0.01 & Nov 01, 2016 & $5,148.91$ & -0.05 \\
\hline Aug 01, 2013 & $4,195.09$ & -0.09 & Apr 01, 2015 & $5,086.43$ & -0.08 & Dec 01, 2016 & $5,296.71$ & 0.03 \\
\hline Sep 01, 2013 & $4,316.18$ & 0.03 & May 01, 2015 & $5,216.38$ & 0.03 & Jan 01, 2017 & $5,294.10$ & 0.00 \\
\hline Oct 01,2013 & $4,510.63$ & 0.05 & Jun 01,2015 & $4,910.66$ & -0.06 & Feb 01, 2017 & $5,386.69$ & 0.02 \\
\hline Nov 01, 2013 & $4,256.44$ & -0.06 & Jul 01, 2015 & $4,802.53$ & -0.02 & Mar 01, 2017 & $5,568.11$ & 0.03 \\
\hline Dec 01, 2013 & $4,274.18$ & 0.00 & Aug 01, 2015 & $4,509.61$ & -0.06 & Apr 01, 2017 & $5,685.30$ & 0.02 \\
\hline Jan 01, 2014 & $4,418.76$ & 0.03 & Sep 01, 2015 & $4,223.91$ & -0.06 & May 01, 2017 & $5,738.16$ & 0.01 \\
\hline Feb 01, 2014 & $4,620.22$ & 0.05 & Oct 01,2015 & $4,455.18$ & 0.05 & Jun 01, 2017 & $5,829.71$ & 0.02 \\
\hline Mar 01, 2014 & $4,768.28$ & 0.03 & Nov 01, 2015 & $4,446.46$ & 0.00 & Jul 01, 2017 & $5,840.94$ & 0.00 \\
\hline Apr 01, 2014 & $4,840.15$ & 0.02 & Dec 01, 2015 & $4,593.01$ & 0.03 & Aug 01, 2017 & $5,864.06$ & 0.00 \\
\hline May 01, 2014 & $4,893.91$ & 0.01 & Jan 01, 2016 & $4,615.16$ & 0.00 & Sep 01, 2017 & $5,900.85$ & 0.01 \\
\hline Jun 01,2014 & $4,878.58$ & 0.00 & Feb 01, 2016 & $4,770.96$ & 0.03 & Oct 01,2017 & $6,005.78$ & 0.02 \\
\hline Jul 01, 2014 & $5,088.80$ & 0.04 & Mar 01, 2016 & $4,845.37$ & 0.02 & Nov 01, 2017 & $5,952.14$ & -0.01 \\
\hline Aug 01, 2014 & $5,136.86$ & 0.01 & Apr 01, 2016 & $4,838.58$ & 0.00 & Dec 01, 2017 & $6,355.65$ & 0.07 \\
\hline
\end{tabular}

Jurnal Manajemen Indonesia 


\begin{tabular}{|c|c|c|c|c|c|c|c|c|}
\hline Tanggal & Close* & Return & Tanggal & Close* & Return & Tanggal & Close* & Return \\
\hline Sep 01, 2014 & $5,137.58$ & 0.00 & May 01, 2016 & $4,796.87$ & -0.01 & Jan 01, 2018 & $6,605.63$ & 0.04 \\
\hline Oct 01, 2014 & $5,089.55$ & -0.01 & Jun 01, 2016 & $5,016.65$ & 0.05 & Feb 01, 2018 & $6,597.22$ & 0.00 \\
\hline Nov 01, 2014 & $5,149.89$ & 0.01 & Jul 01, 2016 & $5,215.99$ & 0.04 & Mar 01, 2018 & $6,188.99$ & -0.06 \\
\hline Dec 01, 2014 & $5,226.95$ & 0.01 & Aug 01, 2016 & $5,386.08$ & 0.03 & & & \\
\hline \multicolumn{8}{|c|}{ Average Retun Pasar } & \\
\hline
\end{tabular}

JURNAL

MANAJEMEN

INDONESIA

Vol.18 No.1

Saham yang merupakan kandidat portofolio optimal merupakan saham dengan expected

April 2018 return yang lebih dari return pasar yaitu 0.00407. Saham saham tersebut antara lain: AKRA, ADRO, BPRT, ICBP, INCO, MYRX, PTBA, PTPP, PWON, TPIA, UNTR, UNVR and WSKT.

\begin{tabular}{|l|l|l|l|l|l|l|l|l|l|l|l|l|l|}
\hline CODE & AKRA & ADRO & BPRT & ICBP & INCO & MYRX & PTBA & PTPP & PWON & TPIA & UNTR & UNVR & WSKT \\
\hline AKRA & 0.013 & 0.012 & 0.006 & 0.001 & 0.011 & 0.001 & 0.012 & -0.001 & -0.001 & 0.004 & 0.002 & -0.001 & -0.001 \\
\hline ADRO & 0.012 & 0.013 & 0.007 & 0.001 & 0.010 & 0.000 & 0.012 & 0.000 & -0.001 & 0.004 & 0.003 & -0.001 & 0.000 \\
\hline BPRT & 0.006 & 0.007 & 0.041 & 0.001 & 0.003 & 0.004 & 0.008 & 0.001 & 0.000 & 0.012 & 0.004 & 0.001 & 0.003 \\
\hline ICBP & 0.001 & 0.001 & 0.001 & 0.027 & -0.008 & 0.001 & 0.000 & 0.000 & -0.004 & 0.001 & 0.002 & 0.000 & 0.002 \\
\hline INCO & 0.011 & 0.010 & 0.003 & -0.008 & 0.025 & 0.001 & 0.011 & 0.004 & 0.000 & 0.003 & 0.002 & -0.002 & 0.002 \\
\hline MYRX & 0.001 & 0.000 & 0.004 & 0.001 & 0.001 & 0.009 & 0.002 & 0.001 & -0.001 & -0.001 & -0.001 & 0.000 & 0.001 \\
\hline PTBA & 0.012 & 0.012 & 0.008 & 0.000 & 0.011 & 0.002 & 0.018 & 0.001 & 0.001 & 0.005 & 0.002 & -0.001 & 0.002 \\
\hline PTPP & -0.001 & 0.000 & 0.001 & 0.000 & 0.004 & 0.001 & 0.001 & 0.013 & -0.001 & 0.001 & 0.001 & 0.000 & 0.011 \\
\hline PWON & -0.001 & -0.001 & 0.000 & -0.004 & 0.000 & -0.001 & 0.001 & -0.001 & 0.010 & 0.002 & -0.001 & 0.001 & -0.001 \\
\hline TPIA & 0.004 & 0.004 & 0.012 & 0.001 & 0.003 & -0.001 & 0.005 & 0.001 & 0.002 & 0.023 & 0.003 & -0.001 & 0.001 \\
\hline UNTR & 0.002 & 0.003 & 0.004 & 0.002 & 0.002 & -0.001 & 0.002 & 0.001 & -0.001 & 0.003 & 0.005 & 0.000 & 0.000 \\
\hline UNVR & -0.001 & -0.001 & 0.001 & 0.000 & -0.002 & 0.000 & -0.001 & 0.000 & 0.001 & -0.001 & 0.000 & 0.003 & 0.001 \\
\hline WSKT & -0.001 & 0.000 & 0.003 & 0.002 & 0.002 & 0.001 & 0.002 & 0.011 & -0.001 & 0.001 & 0.000 & 0.001 & 0.017 \\
\hline
\end{tabular}

Dari tabel di atas terlihat bahwa kovarians di antara dua saham bervariasi dan bernilai positif dan negatif. Kovarians yang negatif menunjukkan bahwa return saham A dan B akan bergerak dengan arah yang berlawanan, yaitu rugi di satu saham akan dikompensasi dengan untung di saham yang lain. Investasi pada saham dengan kovarians yang negatif di dalam portofolio akan mengurangi bahkan dapat menghilangkan semua resiko Sebaliknya, nilai kovarians yang positif menunjukkan nilai-nilai dari dua variabel yang bergerak dengan arah yang sama, yaitu jika satu saham meningkat, maka yang lainnya juga meningkat. (Jogiyanto, 2016).

Proporsi saham yang membentuk portofolio optimal model Markowitz didapatkan melalui hasil perhitungan pada aplikasi solver yang disajikan pada tabel 4 .

Tabel 4.

Covarians dua saham

Sumber : Data diolah

(2018)

Tabel 5.

\begin{tabular}{|c|c|c|}
\hline No & Code & Solver Value \\
\hline 1 & AKRA & 0.034 \\
\hline 2 & ADRO & 0.033 \\
\hline 3 & BPRT & 0.00 \\
\hline 4 & ICBP & 0.047 \\
\hline 5 & INCO & 0.026 \\
\hline
\end{tabular}

Proporsi Saham dalam Portofolio Optimal

Sumber: Data Diolah

(2018) 


\begin{tabular}{|c|c|c|}
\hline 6 & MYRX & 0.136 \\
\hline 7 & PTBA & 0.00 \\
\hline 8 & PTPP & 0.049 \\
\hline 9 & PWON & 0.113 \\
\hline 10 & TPIA & 0.010 \\
\hline 11 & UNTR & 0.157 \\
\hline 12 & UNVR & 0.395 \\
\hline 13 & WSKT & 0.00 \\
\hline
\end{tabular}

Dari Tabel 4.4, hasil dari aplikasi solver menunjukkan proporsi yang berbeda-bedar dari 10 saham pembentuk portofolio optimal, sebagai berikut: AKRA (3.4\%), ADRO (3.3\%), ICBP (4.7\%), INCO (2.6\%), MYRX (13.6\%), PTPP (4.9\%), PWON (11.3\%), TPIA (1\%), UNTR (15.7\%) dan UNVR (39.5\%) sedangkan BPRT, PTBA dan WSKT tidak termasuk ke dalam portfolio optimal. Dari hasil aplikasi Solver juga didapatkan nilai rata-rata return bulanan dari portofolio yaitu sebesar $1.22 \%$ dan resiko (standar deviasi) portofolio yaitu sebesar 0.0312. Besarnya nilai resiko Portofolio masih di bawah resiko (standar deviasi) dari masing-masing saham pembentuk portofolio optimal yang tertera pada tabel 4.1. Hal tersebut menunjukkan bahwa melalui pembentukan portofolio optimal menggunakan model Markowitz dapat memberikan kombinasi portofolio yang dapat meminimalkan resiko.

\section{Kesimpulan dan Saran}

Berdasarkan hasil penelitan, saham-saham pada Jakarta Islamic Index (JII) tahun 2018 yang membentuk portofolio optimal berdasarkan model Markowitz antara lain: AKRA (3.4\%), ADRO (3.3\%), ICBP (4.7\%), INCO (2.6\%), MYRX (13.6\%), PTPP (4.9\%), PWON (11.3\%), TPIA (1\%), UNTR (15.7\%) dan UNVR (39.5\%) sedangkan BPRT, PTBA dan WSKT tidak termasuk ke dalam portofolio optimal. Dari hasil solver didapatkan nilai rata rata tingkat pengembalian portofolio adalah sebesar $1.22 \%$ dan resiko portofolio adalah sebesar 0.0312. Resiko tersebut di bawah resiko dari masing-masing saham individual.

Dalam melakukan proses pemilihan portofolio, investor dapat melakukan diversifikasi saham yaitu memilih beberapa saham yang akan dimasukkan ke dalam portofolio. Proses diversifikasi akan dapat menurunkan resiko dibandingkan dengan investasi pada satu jenis saham saja. Di pasar modal, investor dapat memilih saham-saham yang termasuk ke dalam indeks tertentu karena saham yang termasuk ke dalam indeks merupakan saham-saham yang terpilih berdasarkan kinerja tertentu seperti memiliki likuiditas yang tinggi dan memiliki kinerja yang baik sehingga layak untuk dijadikan sebagai kandidat dalam portofolio.

\section{Daftar Pustaka}

Ahmad, K. (2004). Dasar-dasar manajemen Investasi. Jakarta: PT. Rineka Cipta.

Husnan, S. (2001). Dasar-dasar teori portofolio dan analisis sekuritas. Yogyakarta: Unit Penerbit dan Percetakan AMP YKPN.

Jogiyanto. (2016). Teori Portofolio dan Analisis Investasi. Edisi kesepuluh. Yogyakarta: BPFE-Yogyakarta.

Septyanto, D., \& Kertopati, B. (2017). Analisis pembentukan portofolio dengan menggunakan Model Markowitz dan Single Index Model pada saham yang masuk dalam Indeks Lq45 di Bursa Efek Indonesia tahun 2009-2013. Jurnal Keuangan dan Perbankan, 16(2).

Sharpe, W., Alexander, G. dan Bailey, J. (2005). Investasi. Edisi keenam. Jakarta: Indeks, Prentice Hall, Inc.

Jurnal Manajemen Indonesia 
Susanto, B. (2009). Pasar modal syariah: tinjauan hukum. UII Press.

Tandelilin, E. (2017). Pasar Modal: Manajemen Portofolio dan Inevstasi. Yogyakarta: PT. Kanisius.

Umam, K. (2013). Pasar Modal Syariah \& Praktik Pasar Modal Syariah. Bandung: Pustaka Setia.

JURNAL

MANAJEMEN

www.idx.co.id

INDONESIA

Zubir, Z. (2011). Manajemen Portofolio: Penerapannya dalam Investasi Saham. Jakarta: Salemba Empat.

Vol.18 No.1

April 2018 